\title{
SOCIAL IMPACT OF E-GOVERNMENT IN URBAN MARKETING
}

\author{
Stefany Cevallos ${ }^{1}$
}

DOI: $10.24989 /$ ocg.338.19

\begin{abstract}
The New Technologies of the Information and Communication (ICT) bet by a new model of city in function of the new social needs and the construction of an image for their own countries and the international arena. This research questions and describe the social impact of eGovernment in the construction of the cities to attract Foreign Direct Investment (FDI). Public management plays a fundamental role in the development of different programs in the field of the digitalization of services to generate viable solutions to improve the quality of life of its inhabitants. Urban marketing and the ICT are a fundamental support for these. Citizens, businesses, governments and employees are a policy priority because cities are key factors for the new industrial scenario to converge all segments of society for ICT deployment and use. In addition, the paper presents the progress on e-government service development to understand that social impacts on social groups within a community in advance of the decision making process such as quality of housing, local services, living environment, cultural and political inclination, transportation condition, etc.
\end{abstract}

Keywords: eGovernment, urban marketing, ICT, FDI, society

\section{The e-government for good governance}

The United Nation specialized agency for ICTs, International Telecommunication Union (ITU) estimates that 4.1 billion people have used the Internet at the end of 2019 [11]. As ICT has become pervasive it is more inseparable from social structures. It involves social, cultural, economic and political factors.

Those State capacities necessary to provide services and public goods under the new logic of Statecitizen interaction that configure ICT are in continuous development. In this context, e-government policies offer excellent opportunities to transform public administrations into instruments of sustainable development. Even if the adoption of e-government responds to a multiplicity of variables that exceed the issue of technological infrastructure.

E-government is seen as the most important accountability for citizens in the construction of business scenario. Besides, ICT implementation contributes positively to effectiveness and efficiency in the public sector. Nowadays, public institutions saving huge amount of money in their budgets by reducing the expenses in materials and human resources destined to the collection of taxes when citizens can make their payment online at any time.

1 Stefany Cevallos, Ph. D. student - National University of Public Service, Budapest - Hungary email: stefy220_@hotmail.com 
In this framework, governance connotes a sense of direction in the capacity of action of the government by means of steering. Nevertheless, its difficulty to assign a sole definition to governance, since this term changed from being descriptive to being analytical. "Governance is itself the object of a theoretical debate in which the diversity of traditions and currents in the social sciences is reflected" [8].

What makes the conceptualization of "good" governance doubtful is not so much its normative character as its propensity to reiterate practices around a small number of criteria such as effectiveness, profitability, accountability, participation and transparency. However, these criteria have no value outside the socio-political context in which they are observed [8].

If we were taking about the benefits associated with ICT implementation within the structures of government administrations. There are three types of results can be identified: (a) improvements in government administrative processes and circuits; (b) cost reduction and efficiency increase in the transactional services provided by the government to its citizens; (c) increased democratic legitimacy and transparency of governments.

In part, this is due to that new technologies contribute to generating a more direct relationship between citizens and the government and allow them an increase in trust towards the rulers: citizens participate more than them because there is more information and public debate on what is enriched and enhanced.

When e-government reach a high degree of maturity or sophistication and allows a multilateral exchange of information and services, generates high rates of participation, transparency, citizenship and promotion of democratic values. There are vital tools to empower and expand civil society as it allows the construction of a more active, informed and involved citizenship as well as an increase in the effectiveness in the provision of services and in government processes [15]. In this regard, closer interaction between government and citizenship contributes to the quality of Governance. Of course, there are pessimism and distrust with which politics is looked at today and which tend to limit the normal development of social life [9].

\section{Urban marketing}

Urban marketing research is a young field of study. The are several new dimensions and theoretical contributions to this concept. Since the late 1980s when Ashworth (1989) first analysed the urban tourist phenomenon to begin to understand tourism in the city and embrace urban studies and its theoretical critiques [4].

Urban marketing and city branding, both concepts are intrinsically linked, but on this research urban marketing is the reason we must focus attention on citizens and their willingness to adopt ICT through different e-government strategies. Efforts to increase citizens' confidence in these mechanisms so that they not only request information from governments but also participate in transactional activities with state bureaucracies.

For urban marketing approaches to promote social, supportive and inclusive development in rural, urban marginal sectors, communities and priority groups, through intensive use of ICT would become the configuration of branding to convert to ICT in one of the axes of productive transformation and economic development. 
Governments of all levels, whether national, provincial or municipal, face multiple and interdependent challenges in managing scarce assets with the objective of creating opportunities for all citizens, reducing poverty and improving the living conditions of the population.

To attract investors, cities compete to be smart cities. The digitalization is an advantages for a competitiveness country: Big data, cloud computing technology and increased departmental communication; have been described as recent development trends in E-Government [17].

FDI is defined as the establishment of a lasting interest in and significant degree of influence over the operations of an enterprise in one economy by an investor in another economy [14]. With such decision, it may be possible to achieve enhanced levels of sustainability and governance. Some of the benefits include the following: 1.- Efficient resource utilization, 2.- better quality of life: with better services, efficient living models and the availability of enough information to make informed decision. And the most important, higher levels of transparency and openness. Big data is one example will drive the interoperability and openness to higher levels.

Enabling businesses and entrepreneurs to thrive is of enormous value to citizens, national governments and countries. When the entrepreneurial spirit is supported, economic value will increase, jobs will be created, and personal lives will be enriched. Governments and the countries have their role to play supporting their operations, creating and enforcing the framework in which businesses can operate fairly. Governments and businesses need to communicate in the form of governmental services. These services form the two business related life events that are part of the eGovernment Benchmark; and Regular business operations [7].

In fact, practicing good governance is not enough in this highly competitive marketplace because politicians need to market their good governance practices in order to make the country more attractive to investors [5].

\section{Preliminary balance}

When we are studying the social impact and decision making in housing local services, living environment, cultural inclination and transportation condition. The art of governing implies the way in which they occur or not government capabilities [12]. We should begin by understanding the responsibilities were divided by the administrative decentralization of 1982 . This reorganization of political forces offer to territorial authorities more performance capability, as well as greater autonomy, including developing planning. The development issue becomes more "local".

After 30 years of territorial planning centralized, we are currently in a moment of competition between cities and territories, both nationally and internationally. The competition is open to attract public and private investments of multinational companies and is also the main objective of numerous municipalities.

By way of a few examples, operations that prestige the city are pursued, such as development of technopolos, train stations or international airports, multi-modal platforms, the construction of standing buildings in the heart of the city or the execution of sports or cultural events whose scope exceeds national borders. On the other hand, original communication strategies are developed, and tax advantages are proposed to create a good economic climate. 
The local economic spaces are different from each other and various strategies for valuing their resources place them in a competitive situation. This spatial competition constitutes one of the most important elements of contemporary economic dynamics in urban marketing. Centralization of government power accompanies advances in information and communications technology, as political elites use branding strategy to impose discipline on their messengers and on media coverage [13].

In any case, it is also necessary to reflect on the role played by national governments and the interference functions they display in terms of the promotion of electronic government at the local government level. On some occasions providing basic infrastructure, in others transferring knowledge and management skills, but mainly as regional articulators and coordinators, providing resources to local governments, and implementing strategies for their development.

However, when analysing some cases about national organizations, such as the Tax Collection Entities [6], a better performance in electronic government matters is observed than at the subnational level. When public administrations, at their different levels, implement ICT in the provision of services, they radically modify the form of interaction with citizens. From this perspective, the government is available 24 hours a day, 365 days a year as a result of a dynamic and permanent exchange between the different actors and institutions of the State, the market and civil society. The implementation of ICT contributes positively to the effectiveness and efficiency of the public sector while allowing a significant cost reduction [2].

Government agencies save significant percentages of the budget by reducing expenditures on materials and human resources for collecting taxes when citizens can make their payment online at any time. Government presence is seen in the enhancement of the quality of life for a segment-city citizens-through utilizing information technology hardware, software, networks, and data on different city areas and services [2]. The increase in efficiency occurs in two planes. On one hand, citizens timing is reduced to carry out transactions; both of those who access virtually and of those who approach the physical headquarters of the government. On the other hand, governments centralize and systematize the collection of contributions and fees in virtual agencies. However, the availability of e-administration in the absence of administrative physical presence does not guarantee its use [10].

There are many social impact in developing countries but in essence just to mention different types of obstacles to the development of e-government policies: speed in technological innovation, lack of continuity in political decisions regarding the development of electronic government policies, and the absence of a macro-level public policy that promotes the coordination of this type of initiatives at a general and homogeneous level [16].

In addition, the increase in internet access has benefited from the rapid spread of smartphones, facilitating access to populations that were in places where the land connection was poor or nonexistent [3].

\section{Conclusions}

Political participation and the relationship between citizens and the government has been affected because of social inequalities, migration and the use of ICT. There are positive and negative effects in urban marketing. On the other hand, there is still a lack in studies on why the relationship between 
e-government and FDI should exist and why some of these factors can relate to ICT and specially egovernment.

The dissemination of ICTs has also been given thanks to more adaptive cultural habits and customs, and even a much younger demographic profile than in developed countries. Furthermore, the digitalization of the public sector has been a process with good results when replacing certain physical administration is something relative and limited. Relative, because it was better than having no presence; limited, because the services and procedures offered have been mostly nationals, since many are in the hands of decentralized entities.

\section{References}

[1] AL-ADAWI et al., "Conceptual model of citizen adoption of e-government" en 2da Conferencia Internacional sobre Innovación en información tecnológica 2005.

[2] AL NUAIMI, E., AL NEYADI, H., MOHAMED, N. Y AL-JAROODI, J.: Applications of big data to smart cities. Journal of Internet Services and Applications, 6 (1), 25. 2015 http://doi.org/10.1186/s13174-015-0041-5

[3] ALAZZAM, A. and ABU-SHANAB, E., E-government: The gate for attracting foreign investments. 2014 6th International Conference on Computer Science and Information Technology, CSIT 2014 - Proceedings. 161-165. 10.1109/CSIT.2014.6805995.

[4] ASHWORTH, G. J. and VOOGD, H., Selling the city: marketing approaches in public sector urban planning, 1990.

[5] AZAZ ZAMAN, IMTIAZ UDDIN CHOWDHURY, SHARIFUL ISLAM, M.. (2019). Branding Good Corporate Governance: A Pathway to Strengthen Investors' Perception and Brand Equity (Version 10010400). International Journal of Business, Human and Social Sciences, 12.0(5). http://doi.org/10.5281/zenodo.3298821

[6] DIÉGUEZ, G., GASPARÍN, J. and SÁNCHEZ, J., (junio de 2015). Gobierno 58 electrónico y capacidades estatales en América Latina y el caribe. Estudio exploratorio en centros urbanos y agencias tributarias nacionales. Documento de Trabajo N¹32. Buenos Aires: CIPPEC.

[7] European Commission DG Communications Networks, Content \& Technology. eGovernment Benchmark 2019 Empowering Europeans through trusted digital public services (Accessed on January 13, 2020).

[8] FONTAINE, G.. Petropolítica: Una teoría de la gobernanza energética, 2010.

[9] GUZMÁN, L., JUANY, SÁENZ BRECKENRIDGE S., Gobernabilidad, Convivencia política y seguridad 2013.

[10] GOMIS-BALESTRERI, M., Del gobierno electrónico al big data: la digitalización de la gestión pública en Colombia frente al control territorial. opera, 21, pp. 25-53 2017. doi: https://doi.org/10.18601/16578651.n21.03 
[11] International Telecommunication Union. 2019. "Electronic Government for Developing Countries" www.itu.int/ITU-D/ (Accessed on December 10, 2019).

[12] LERNER, B., UVALLE R. and MORENO R., Moreno. Gobernabilidad y gobernanza en los albores del siglo XXI y reflexiones sobre el México contemporáneo, 2012.

[13] MARLAND, A., LEWIS, J. and FLANAGAN, T., (2017). Governance in the Age of Digital Media and Branding. Governance. 30. 125-141. 10.1111/gove.12194.

[14] OECD, Measuring International Investment by Multinational Enterprises Implementation of the OECD's Benchmark Definition of Foreign Direct Investment, 4th edition 2015. (Accessed on December 10,2019).

[15] RUBINO HALLMAN, S., "E-Government in Latin America and the Caribbean. Reinventing governance in the information age" presentado en CLAD sobre Reforma del Estado $y$ Modernización de la Administración Pública, Caracas 2002.

[16] SANDOVAl AlMAZÁN, R., and GIL, G. J., Propuesta de evaluación para portales de gobierno electrónico basada en el enfoque evolutivo. Revista Chilena de Administración Pública(14), 83 a 1222009.

[17] WOODSIDE, J., AMIRI, S., and BOLDRIN, B., The Impact of ICT and Big Data on eGovernment 2015. 